\title{
Effect of personal exposure to black carbon on changes in allergic asthma gene methylation measured 5 days later in urban children: importance of allergic sensitization
}

Kyung Hwa Jung ${ }^{1}$, Stephanie Lovinsky-Desir², Beizhan Yan³, David Torrone', Jennifer Lawrence ${ }^{1}$, Jacqueline R. Jezioro', Matthew Perzanowski ${ }^{4}$, Frederica P. Perera ${ }^{4}$, Steven N. Chillrud ${ }^{3}$ and Rachel L. Miller ${ }^{1,4,5^{*}}$

\begin{abstract}
Background: Asthma gene DNA methylation may underlie the effects of air pollution on airway inflammation. However, the temporality and individual susceptibility to environmental epigenetic regulation of asthma has not been fully elucidated. Our objective was to determine the timeline of black carbon (BC) exposure, measured by personal sampling, on DNA methylation of allergic asthma genes 5 days later to capture usual weather variations and differences related to changes in behavior and activities. We also sought to determine how methylation may vary by seroatopy and cockroach sensitization and by elevated fractional exhaled nitric oxide (FeNO).

Methods: Personal BC levels were measured during two 24-h periods over a 6-day sampling period in 163 New York City children (age 9-14 years), repeated 6 months later. During home visits, buccal cells were collected as noninvasive surrogates for lower airway epithelial cells and FeNO measured as an indicator of airway inflammation. CpG promoter loci of allergic asthma genes (e.g., interleukin 4 (IL4), interferon gamma (IFNY), inducible nitric oxide synthase (NOS2A)), arginase 2 (ARG2)) were pyrosequenced th the start and end of each sampling period.

Results: Higher levels of $\mathrm{BC}$ were associated with lower methylation of IL4 promoter $\mathrm{CpG}^{-48} 5$ days later. The magnitude of association between $\mathrm{BC}$ exposure and demethylation of IL4 $\mathrm{CpG}^{-48}$ and NOS2A CpG ${ }^{+5099}$ measured 5 days later appeared to be greater among seroatopic children, especially those sensitized to cockroach allergens (RR [95\% Cl] $0.55[0.37-0.82]$ and $0.67[0.45-0.98]$ for IL4 $\mathrm{CpG}^{-48}$ and NOS2A CpG ${ }^{+5099}$, respectively), compared to non-sensitized children (RR [95\% CI] 0.87 [0.65-1.17] and 0.95 [0.69-1.33] for IL4 $\mathrm{CpG}^{-48}$ and NOS2A CpG ${ }^{+5099}$, respectively); however, the difference was not statistically different. In multivariable linear regression models, lower DNA methylation of $\mathrm{IL} 4 \mathrm{CpG}^{-48}$ and NOS2A CpG ${ }^{+5099}$ were associated with increased FeNO.
\end{abstract}

Conclusions: Our results suggest that exposure to BC may exert asthma proinflammatory gene demethylation 5 days later that in turn may link to airway inflammation. Our results further suggest that seroatopic children, especially those sensitized to cockroach allergens, may be more susceptible to the effect of acute BC exposure on epigenetic changes.

Keywords: Personal monitoring, Black carbon exposure, Changes in DNA methylation, Pediatric asthma, Allergic sensitization

\footnotetext{
* Correspondence: rlm14@cumc.columbia.edu

'Division of Pulmonary, Allergy, Critical Care Medicine, Department of

Medicine, Columbia University College of Physicians and Surgeons, PH8E-101,

630 W. 168 St., New York, NY 10032, USA

${ }^{4}$ Mailman School of Public Health, Department of Environmental Health

Sciences, Columbia University, 722 W. 168 St., New York, NY 10032, USA

Full list of author information is available at the end of the article
} 


\section{Background}

Exposure to air pollution including black carbon (BC) or soot, a major component of fine particulate matter $(\mathrm{PM})_{2.5}$, has been associated with worsening of asthma symptoms and airway inflammation among urban children $[1,2]$. Understanding the temporality and mechanisms underlying the effects of $\mathrm{BC}$ exposure on airway inflammation may help direct environmental remediation, identify the time when health care needs are greater, and identify those at higher risk.

Cohort studies have suggested that acute (e.g., same day) and subacute (e.g., cumulative over days to one week) exposures to $\mathrm{BC}$ may exacerbate respiratory symptoms and increase airway inflammation among urban children [2-4]. Others have identified short-term lag effects (e.g., up to 5 days) of measures of air pollution on airway-related outcomes $[2,3,5]$. The individual dose of $\mathrm{BC}$ can vary significantly over days due to changes in personal behavior or activities [6] and over many days or 1 week related to variations in weather patterns in NYC [7-9]. Therefore, the wide variability in temporality between pollutant exposure and disease outcomes suggests that further refinement of the timeline of BC's effects is needed. This can be achieved by understanding the timeline of the underlying mechanism that influences the relationship between BC and airwayrelated outcomes.

Environmental epigenetic regulation, including DNA methylation, is increasingly recognized as an important mechanism underlying the effects of air pollution on the development of complex diseases like asthma [10]. Exposure to BC, specifically, has been associated with altered DNA methylation of asthma genes in mouse studies [11], and in cohort studies comprised of elderly adults [12], and children [13]. Yet, these few studies have not pinpointed the timeline for environmental epigenetic regulation on asthma risk. Some studies suggest that epigenetic changes can occur relatively quickly and over days $[14,15]$ and in close proximity to short-term environmental exposures [16-18]. Other studies suggest that epigenetic patterns may be relatively stable or long-term $[19,20]$. Moreover, the scarce research to date that has focused on air pollution-related epigenetic regulation of allergic asthma genes in a pediatric urban cohort [21] has not yet assessed the epigenetic consequence of exposure to $\mathrm{BC}$ and its possible effects measured days later. $\mathrm{BC}$, and its diesel exhaust particle (DEP) sources, is important to immunoglobulin $\mathrm{E}$ ( $\mathrm{IgE}$ ) and allergic immune upregulation [22]. However, the differential susceptibility to BC-induced epigenetic changes by atopy, or by the urban asthma risk factor of cockroach sensitization [23, 24], has not been well studied.

Our objective was to determine the temporality of $\mathrm{BC}$ exposure on DNA methylation of genes and loci previously implicated in urban asthma and/or allergic sensitization (e.g., interleukin 4 (IL4), interferon gamma $(\mathrm{IFN} \gamma$ ), inducible nitric oxide synthase (iNOS encoded by NOS2A), and arginase 2 (ARG2)) [11, 12, 25-32] (Additional file 1: Figure S1) and how it may vary by seroatopy and cockroach sensitization. The key to defining this temporality is our novel determination of a child's individual acute $\mathrm{BC}$ exposure level using personal monitoring. This approach integrates all fluctuating exposure levels by different time-activity patterns, which may also differ by age and sex and other key covariates [33]. We also repeatedly and noninvasively sampled the buccal mucosa to assess DNA methylation because this aerodigestive track epithelium is readily accessible in children [34], and altered methylation of other asthma/allergy genes here has been associated with airway inflammation in children [32]. Repeat measures of DNA methylation enabled us to control for previous DNA methylation levels, thus to assess changes in methylation over time. We measured DNA methylation using pyrosequencing to resolve small differences in methylation in response to acute BC exposure [35-37]. We also sought to determine the relationship between DNA methylation of allergic asthma genes and elevated fractional exhaled nitric oxide (FeNO), a key noninvasive measure of allergic airway disease $[38,39]$ that increases in response to air pollution exposure $[1,40]$. FeNO has been linked specifically to buccal DNA methylation of NOS2A promoter and ARG2 [30, 32]. We hypothesized that daily personal exposure to $\mathrm{BC}$ would exert a short-term change in buccal cell methylation of allergic asthma genes 5 days later among urban children, and that the association between $\mathrm{BC}$ exposure and altered methylation may vary by seroatopy. We also hypothesized that DNA methylation of allergic asthma genes would affect FeNO levels.

\section{Methods}

Study population and personal air monitoring

Participants were recruited from the parent Columbia Center for Children's Environmental Health (CCCEH) birth cohort [41]. For this nested study, 163 children who met criteria for age (9-14 years old) and underwent an evaluation for current asthma, determined by a specialized physician (allergist, pulmonologist) and a report of asthma symptoms or asthma medication use in the 12 months prior to enrollment [42], were recruited as previously described [43]. The study was approved by the Columbia University Institutional Review Board, and written informed consents and assents were obtained.

\section{Assessment of personal BC}

Children wore a vest that contained a MicroAeth (Model AE51, Magee Scientific, Berkley, CA) personal BC monitor that was equipped with a nafion tube air inlet to 
avoid issues related to rapid changes in temperature and relative humidity in the breathing zone (i.e., vest collar). Compliance was assured by comparing accelerometer data from a device within the vest to the one worn on the child's wrist, as described [43]. Personal BC levels were monitored every $5 \mathrm{~min}$ over two 24-h periods $\left(\mathrm{BC}_{1}, \mathrm{BC}_{2}\right) 6$ days apart between March 2012 and August 2015 (Fig. 1). Data were cleaned to remove false positive and negative data that can result from physical vibration following published methods $[44,45]$ and then averaged to yield a mean 24-h BC level. Over $90 \%$ of the first $24 \mathrm{~h}$ periods started on either Wednesday or Thursday to reduce variation in air pollution exposure by day of the week [46], and $60 \%$ were repeated 6 months later ( $n=98$, Additional file 1: Figure S2).

\section{Allergic sensitization}

Total and cockroach allergen IgE levels were measured using Immunocap (Phadia, Uppsala, Sweden) [24]. Sera were collected at ages 7, 9, and 11, and data at age 9 or age 7 were used for the children that did not have a sample available at age 11 . Because previous evidence suggested that combined exposure to traffic-related air pollution and cockroach allergen may worsen urban asthma morbidity [23, 24], primary analyses focused on German cockroach. Children were classified as seroatopic if total IgE $\geq 80 \mathrm{IU} / \mathrm{mL}$ and as cockroach sensitized if they had a specific cockroach $\operatorname{IgE} \geq 0.35 \mathrm{IU} / \mathrm{mL}$ [24].

\section{Buccal sample collection and DNA extraction}

Buccal DNA (BDNA) samples were collected on day 1 $\left(\mathrm{BDNA}_{1}\right)$ and day $6\left(\mathrm{BDNA}_{2}\right)$ using a CytoSoft cytology brush (Fischer Scientific, Pittsburgh, Pennsylvania) during home visits, following each 24-h BC collection
(Fig. 1). DNA extractions were performed using the Gentra Puregene Buccal Cell kit (Qiagen, Germantown, Maryland). Homogeneity of the buccal cell population was assessed as described [47].

\section{DNA methylation}

Targeted promoter region $\mathrm{CpG}$ loci were selected in regions of genes (i.e., IL4, IFN $\gamma$, NOS2A, ARG2) where methylation has been shown to be potentially responsive to traffic-related air pollution or has been implicated in allergy, asthma, and airway inflammation [11, 12, 25-32]. Loci with evidence of conservation between mouse and humans were especially targeted (Additional file 1: Figure S1). PCR and pyrosequencing were performed as reported [15, 47], using methylated and unmethylated DNA as positive and negative controls (Qiagen). $\mathrm{BDNA}_{1}$ and $\mathrm{BDNA}_{2}$ for each subject were amplified and pyrosequenced on the same 96-well plate. A duplicate buccal sample was collected in a subset and pyrosequenced as reported [47].

\section{Measurement of FeNO}

FeNO was measured on day $1\left(\mathrm{FeNO}_{1}\right)$ and day 6 $\left(\mathrm{FeNO}_{2}\right)$ following each 24-h BC collection (Fig. 1), using the offline technique (GE Instruments, Boulder, CO). Three breath samples were collected in individual Mylar balloons at a flow rate of $83 \mathrm{ml} / \mathrm{s}$ [4]. Two ambient NO samples were simultaneously collected with FeNO using a nitric oxide analyzer (GE Instruments, Boulder, $\mathrm{CO}$ ) to account for possible home environmental contamination of our sample. FeNO and ambient NO levels were averaged to obtain mean daily levels of FeNO and ambient NO, respectively. Fifteen percent of FeNO

a Time 1 (March 2012 and August 2015)

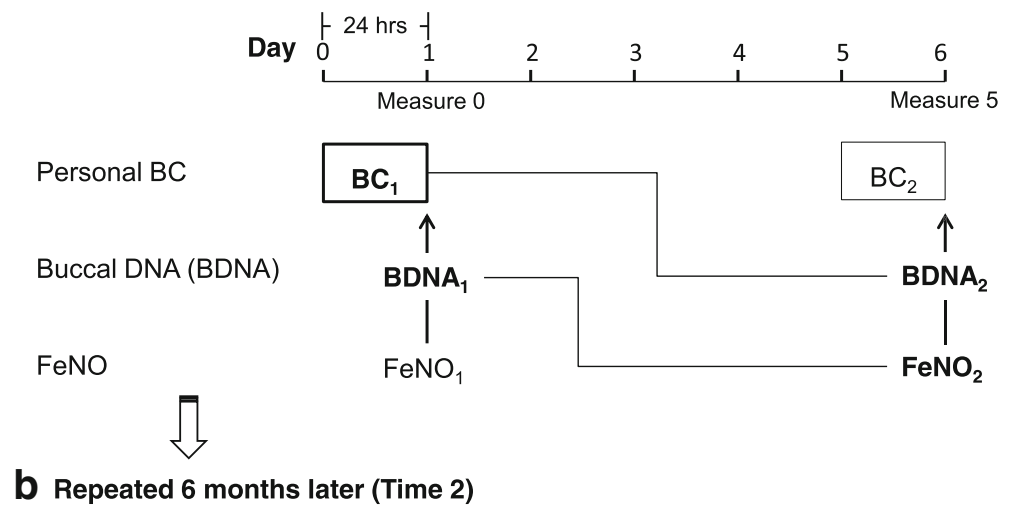

Fig. 1 Study design: a time 1 (March 2012 and August 2015) and b repeated 6 months later (time 2). Personal BC was monitored for $24 \mathrm{~h}$ and collected on day $1\left(\mathrm{BC}_{1}\right)$ and day $6\left(\mathrm{BC}_{2}\right)$; Buccal DNA and FeNO were measured on d1 $\left(\mathrm{BDNA}_{1} ; \mathrm{FeNO}_{1}\right)$ and day $\left.6\left(\mathrm{BDNA}_{2} \text {; FeNO }\right)_{2}\right)$. Sampling was repeated 6 months later (time 2); measure five marks when effects of $B C$ on methylation were measured 5 days later; bolded measures were used in current analyses. $\mathrm{BC}_{2}$ in a thinner box and $\mathrm{FeNO}_{1}$ were not used in the current analyses 
samples were collected but determined invalid due to ambient NO greater than $100 \mathrm{ppb}$.

\section{Statistical analyses}

Analyses were restricted to children who had valid BC and methylation measures and available IgE data, with a final sample size of 143 (Additional file 1: Figure S2). BC and FeNO data were natural log-transformed to normalize skewed distributions. Descriptive statistics were analyzed using chi-square tests, Mann-Whitney tests, and Spearman correlations, as appropriate. Intraclass correlation coefficient (ICC) was calculated for correlations among multiple measures of personal $\mathrm{BC}$ (i.e., $\mathrm{BC}_{1}$ and $\mathrm{BC}_{2}$ at time 1 ) and $\mathrm{FeNO}$ (i.e., $\mathrm{FeNO}_{1}$ and $\mathrm{FeNO}_{2}$ at time 1). Due to the non-normal distribution of log-transformed methylation, the percent methylation of CpG sites within the IL4, IFN $\gamma$, and NOS2A genes were dichotomized at the upper tertile (high (1) vs low (0) methylation) [48]. As previously described [32], percent methylation of ARG2 was averaged across the three selected $\mathrm{CpG}$ sites then further dichotomized as "unmethylated (0)" vs "methylated (1)" if the average percent methylation was equal to zero or greater than zero. Methylation data were used as dichotomous variables (outcome variable) in analyses with personal BC and log-transformed continuous variables (predictor variable) in analyses with FeNO. Percent methylation values, instead of log-transformed data, were used for ARG2 in analyses with FeNO due to zero values in ARG2.

The associations between $\mathrm{BC}$ and changes in DNA methylation 5 days later were analyzed using a modified Poisson regression in generalized estimating equations (GEE) to estimate relative risks (RR) [49]. The results were expressed as RR of methylation in the highest tertile vs the second and lowest (as reference). The analyses were conducted using $\mathrm{BC}_{1}$ (on day 1 ) and $\mathrm{BDNA}_{2}$ (on day 6) with adjustment of $\mathrm{BDNA}_{1}$ (day 1) to assess delayed effects of $\mathrm{BC}$ on changes in DNA methylation over 5 days (Fig. 1). Models included covariates of race/ ethnicity, sex, age, asthma diagnosis, heating season (October to April), obesity (body mass index (BMI) zage- and sex-specific 95th percentile of the year 2000 CDC growth charts), and seroatopy. The subjects were stratified by seroatopy or cockroach sensitization and adjusted models were run (but without controlling for seroatopy or cockroach sensitization) within each stratum. We further tested the interaction between $\mathrm{BC}$ and seroatopy on DNA methylation.

Multivariable linear regression models were used to examine the associations between DNA methylation and FeNO, after controlling for aforementioned covariates and ambient NO levels. The analyses were conducted using $\mathrm{BDNA}_{1}$ (on day 1) and $\mathrm{FeNO}_{2}$ (on day 6) to assess effects of DNA methylation on FeNO measured 5 days later (Fig. 1).

Secondary analyses include (1) analysis on the direct association between $\mathrm{BC}$ and $\mathrm{FeNO}$ measured 5 days later, (2) analysis on same-day association of DNA methylation with $\mathrm{BC}$ and $\mathrm{FeNO}$, and (3) analysis on the association between DNA methylation and lung function outcomes.

Sensitivity analyses were conducted as follows: (1) reanalysis after removing one extreme personal BC concentration (exceeding $16 \mu \mathrm{g} / \mathrm{m}^{3}$ ), (2) reanalysis after controlling for chronic exposure, which was determined by the total percentage of secondary and connecting roads near a child's home address at ages 7,9 , and 11 calculated using geographic information system from the CCCEH geospatial measures of the built and social environments database, (3) reanalysis after controlling for food intake by asking the question "In the past two hours, have you had anything to eat or drink?" and after eliminating current medication by asking the question "In the past 24 hours, have you taken any medications for asthma or allergies?", and (4) reanalysis using the difference between $\mathrm{BDNA}_{1}$ and $\mathrm{BDNA}_{2}$ (i.e., $\mathrm{BDNA}_{2}-$ $\mathrm{BDNA}_{1}$ ) as a continuous outcome in multivariable linear regression models. All analyses were performed using SPSS Statistic version 23.0 (SPSS Inc., Chicago, IL) where $p<0.05$ was considered statistically significant.

\section{Results}

\section{Cohort characteristics}

Characteristics of the 143 children along with personal $\mathrm{BC}$ and FeNO concentrations are presented in Table 1. There were no significant differences in demographic variables between seroatopic and nonatopic children except a higher frequency of obesity among the seroatopic children. Compared to the 584 CCCEH cohort children who did not meet the inclusion criteria for the nested study and thus were not enrolled, the enrolled children who were recruited to have a greater proportion of asthmatics also had a higher proportion of maternal asthma and cockroach sensitization (Additional file 1: Table S1).

\section{Personal exposure to $\mathrm{BC}$}

Overall, urban children living in NYC were exposed to $1.21 \mu \mathrm{g} / \mathrm{m}^{3}$ of 24-h geometric mean levels of $\mathrm{BC}_{1}$. Personal BC levels did not differ by seroatopy (Table 1). Substantial changes in personal BC levels were observed within 5 days, with $28 \%$ of children experiencing greater than the interquartile range changes (IQR increase or decrease) between $\mathrm{BC}_{1}$ and $\mathrm{BC}_{2}$. Repeated measures of $\mathrm{BC}$ showed ICCs of 0.37 (5 days apart), indicating substantial within-subject variations in $\mathrm{BC}$ levels. 
Table 1 Cohort characteristics ( $N=143)$

\begin{tabular}{|c|c|c|c|}
\hline Characteristic & $\begin{array}{l}\text { Seroatopy }^{\mathrm{a}} \\
(n=75)\end{array}$ & $\begin{array}{l}\text { Non-atopy } \\
(n=68)\end{array}$ & $P$ value $^{h}$ \\
\hline Maternal ethnicity & & & 0.34 \\
\hline Dominican & $45 / 75(60 \%)$ & $46 / 68(68 \%)$ & \\
\hline African American & $30 / 75(40 \%)$ & 22/68 (32\%) & \\
\hline Age mean [min-max], years & $12.7[10.4-14.3]$ & $12.8[10.5-14.0]$ & 0.40 \\
\hline Girls & $38 / 75(51 \%)$ & $39 / 68(57 \%)$ & 0.42 \\
\hline $\begin{array}{l}\text { Maternal high-school } \\
\text { degree or greater }\end{array}$ & 40/74 (54\%) & $38 / 63(60 \%)$ & 0.46 \\
\hline Maternal asthma (+) & 23/75 (31\%) & 19/68 (28\%) & 0.72 \\
\hline Prenatal ETS exposure ${ }^{\mathrm{b}}(+)$ & 23/74 (31\%) & $22 / 67(33 \%)$ & 0.62 \\
\hline Current ETS exposure ${ }^{c}(+)$ & $7 / 67(10 \%)$ & $8 / 60(13 \%)$ & 0.82 \\
\hline Asthma $^{d}$ & $44 / 75(59 \%)$ & $30 / 68$ (44\%) & 0.08 \\
\hline $\mathrm{BMI}^{\mathrm{e}} \mathrm{z}$ score, median $[\mathrm{IQR}]$ & $1.15[1.43]$ & $0.91[1.35]$ & 0.28 \\
\hline Overweight ( $\geq 85$ th percentile) & $40 / 75(53 \%)$ & $33 / 68(49 \%)$ & 0.57 \\
\hline Obesity ( $\geq 95$ th percentile) & $24 / 75(32 \%)$ & 12/68 (18\%) & $<0.05$ \\
\hline \multicolumn{4}{|l|}{ Personal $B C^{f} \mu \mathrm{g} / \mathrm{m}^{3}$, median $[\mathrm{IQR}]$} \\
\hline Day 1 & $1.23[1.01]$ & $1.27[1.07]$ & 0.68 \\
\hline Day 6 & $1.12[1.25]$ & $1.24[1.29]$ & 0.45 \\
\hline \multicolumn{4}{|l|}{ FeNO ppb ${ }^{9}$, median [IQR] } \\
\hline Day 1 & 14.5 [15.3] & $8.8[8.85]$ & $<0.01$ \\
\hline Day 6 & $15.4[12.4]$ & $9.3[8.81]$ & $<0.01$ \\
\hline
\end{tabular}

$I Q R$ interquartile range

${ }^{a}$ Total IgE $\geq 80 \mathrm{IU} / \mathrm{ML}$ at age 7,9 , or 11 year

${ }^{\mathrm{b}}$ Report of any smoker in the house during pregnancy

'Report of any smoker in the home during the 1-week

sampling period

${ }^{d}$ Determined by a specialist physician using standardized criteria at age $5-12$ years [42]

${ }^{\mathrm{e}}$ Body mass index (BMI) calculated by weight $(\mathrm{kg}) /$ height $(\mathrm{m})^{2}$

standard deviation (SD)

fPersonal BC measured at time 1

${ }^{9} \mathrm{FeNO}$ measured at time $1, n=31$ missing due to either invalid data or ambient NO $>100 \mathrm{ppb}$

${ }^{h}$ Chi-square test for categorical variables and Mann-Whitney test for continuous variables (age, BMI z score, personal BC, and FeNO)

\section{Effects of BC on changes in DNA methylation of allergic asthma genes measured 5 days later}

Descriptive statistics of DNA methylation on days 1 and 6 are shown in Additional file 1: Table S2. Further details also have been published [47]. DNA methylation of allergic asthma genes measured on day 1 (BDNA $)_{1}$ correlated weakly with those measured on day $6\left(\mathrm{BDNA}_{2}\right)$ (Additional file 1: Figure S3). The methylation levels at each of the $\mathrm{CpG}$ loci on day $1\left(\mathrm{BDNA}_{1}\right)$ did not differ by seroatopy (Mann-Whitney test, $p>0.05$ ). Higher levels of $\mathrm{BC}$ were associated with lower methylation of IL4 promoter $\mathrm{CpG}^{-48} 5$ days later, with and without controlling for covariates, including previous day 1 methylation of IL4 $\mathrm{CpG}^{-48}$ (Table 2). Similar associations were not apparent between $\mathrm{BC}$ and DNA methylation of other asthma gene promoters (i.e., IFN $\gamma$, NOS2A, and ARG2) in unadjusted and adjusted models (Table 2, $p>0.05$ ).
Table 2 Effects of personal BC exposure on DNA promoter region methylation measured 5 days later: RR of methylation in the highest tertile vs the second and lowest (as reference)

\begin{tabular}{llll}
\hline & & \multicolumn{2}{l}{ Overall effects, RR $[95 \% \mathrm{Cl}]$} \\
\hline Gene & CpG promoter region $^{\mathrm{a}}$ & Unadjusted & Adjusted $^{\mathrm{b}}$ \\
IL4 & -326 & $0.82[0.63-1.06]$ & $0.82[0.63-1.07]$ \\
& -48 & $0.75[0.58-0.96]^{*}$ & $0.77[0.61-0.97]^{*}$ \\
IFNY & -186 & $1.15[0.86-1.53]$ & $1.18[0.88-1.58]$ \\
& -54 & $0.91[0.68-1.20]$ & $0.92[0.68-1.26]$ \\
NOS2A & +5099 & $0.84[0.64-1.09]$ & $0.82[0.65-1.03]$ \\
& +5106 & $1.20[0.91-1.59]$ & $1.21[0.94-1.55]$ \\
ARG2 & $-32,-30$, and $-26^{c}$ & $1.06[0.95-1.18]$ & $1.04[0.94-1.15]$ \\
\hline
\end{tabular}

Note: 86 of the 143 children underwent repeat testing 6 months later allowing for $n=229$ total observations analyzed

${ }^{*} p$ value $<0.05$

${ }^{a} \mathrm{CpG}$ position relative to the transcriptional start site

${ }^{b}$ Adjusted for race/ethnicity, sex, age, asthma diagnosis, obesity, seroatopy, heating season, and DNA methylation at day 1

${ }^{\mathrm{C}}$ Average methylation of ARG2 CpG sites of $-32,-30$, and -26

When stratified by seroatopy, the magnitude of association between $\mathrm{BC}$ exposure and demethylation of IL4 $\mathrm{CpG}^{-48}$ and NOS2A $\mathrm{CpG}^{+5099} 5$ days later appeared to be greater among seroatopy, compared to non-atopy (Fig. 2 and Additional file 1: Table S3). A similar pattern was observed when stratified by cockroach sensitization with smaller RR's (Fig. 2 and Additional file 1: Table S3). However, a significant interaction between $\mathrm{BC}$ and seroatopic or cockroach sensitization on DNA methylation of asthma genes was not observed (Additional file 1: Table S4. $\left.P_{\text {interaction }}>0.05\right)$.

\section{Effects of DNA methylation on FeNO levels measured 5 days later}

Median FeNO was $12.3 \mathrm{ppb}(\min -\max =2.54-85.3 \mathrm{ppb})$ on day $6\left(\mathrm{FeNO}_{2}\right)$. Seroatopic or cockroach-sensitized children exhibited significantly higher levels of FeNO compared to non-atopic children (e.g., median 15.4 vs $9.3 \mathrm{ppb}$ for seroatopic vs non-atopic children; MannWhitney test; $p<0.001)$. ICCs of repeated measures of FeNO were 0.81 ( 5 days apart).

In multivariable linear regression models, lower DNA methylation of IL4 $\mathrm{CpG}^{-48}$ and NOS2A CpG +5099 were associated with higher FeNO, with adjustment of seroatopy and ambient NO, 5 days later (Fig. 3 and Additional file 1: Table S5). However, the associations of FeNO with DNA methylation of other asthma gene promoters (i.e., IFNy and ARG2) were not significant in adjusted models (Additional file 1: Table S5, $p>0.05$ ).

\section{Secondary analyses}

We did not observe a direct association between $\mathrm{BC}$ exposure and FeNO measured 5 days later in an adjusted 


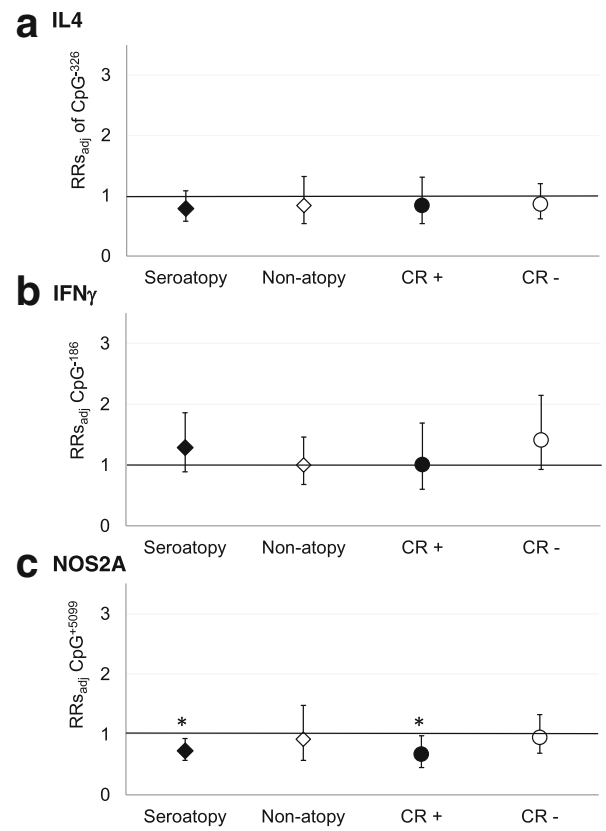

$\begin{array}{ll}\text { - Total IgE } \geq 80 \mathrm{IU} / \mathrm{mL} & \diamond \text { Total } \mathrm{IgE}<80 \mathrm{IU} / \mathrm{mL} \\ \text { - } \mathrm{CR} \operatorname{lgE} \geq 0.35 \mathrm{IU} / \mathrm{mL} & \circ \mathrm{CR} \operatorname{lgE}<0.35 \mathrm{IU} / \mathrm{mL}\end{array}$
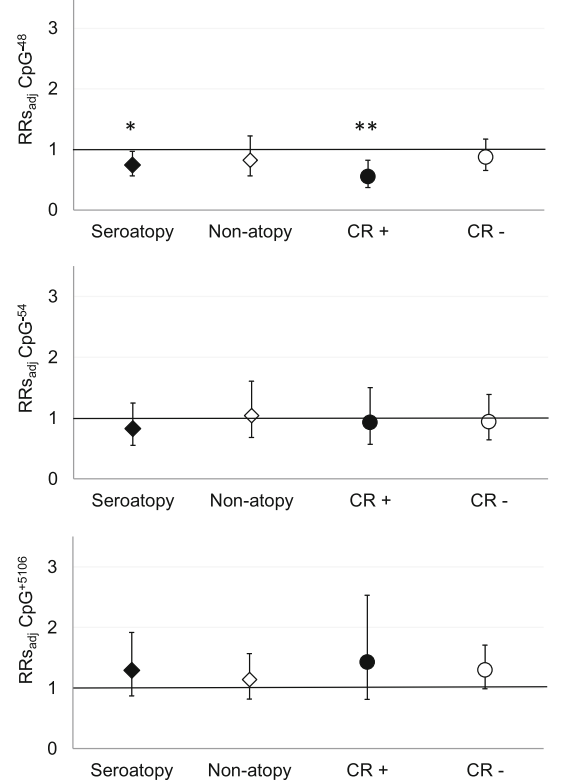

Fig. 2 Effects of personal BC exposure on DNA promoter region methylation 5 days later of a IL4 $\left(\mathrm{CpG}^{-326}, \mathrm{CpG}^{-48}, \mathbf{b} \mathrm{IFNY}\left(\mathrm{CpG}^{-186}, \mathrm{CpG}^{-54}\right)\right.$, and $\mathbf{c}$ NOS2A $\left(\mathrm{CpG}^{+5099}, \mathrm{CpG}^{+5106}\right)$, stratified by allergic sensitization. Relative risk (RR) estimates of DNA methylation of asthma genes and $95 \%$ confidence interval $(\mathrm{Cl})$, for a unit increase in log $B C$ concentrations among seroatopic $\bullet N=75)$, non-atopic $(\bullet N=68)$, cockroach-sensitized $(\cdot C R+N=55)$, and non-sensitized ( $\mathrm{CR}-N=88$ ) children, adjusting for race/ethnicity, sex, age, asthma diagnosis, obesity, season, and DNA methylation on day $1 .{ }^{*} p<0.05$ and ${ }^{* *} p<0.01$

model $(p>0.05)$. We explored same-day associations between $\mathrm{BC}$ and DNA methylation, using both day $1\left(\mathrm{BC}_{1}\right.$ and $\left.\mathrm{BDNA}_{1}\right)$ and day $6\left(\mathrm{BC}_{2}\right.$ and $\left.\mathrm{BDNA}_{2}\right)$ measures in adjusted models. An overall association between $\mathrm{BC}$ exposure and DNA methylation of IL4 $\mathrm{CpG}^{-48}$ and NOS2A $\mathrm{CpG}^{+5099}$ measured on the same day was not significant $(p>0.05)$. Similarly, when same-day associations between DNA methylations and FeNO were examined, previously observed significant associations of

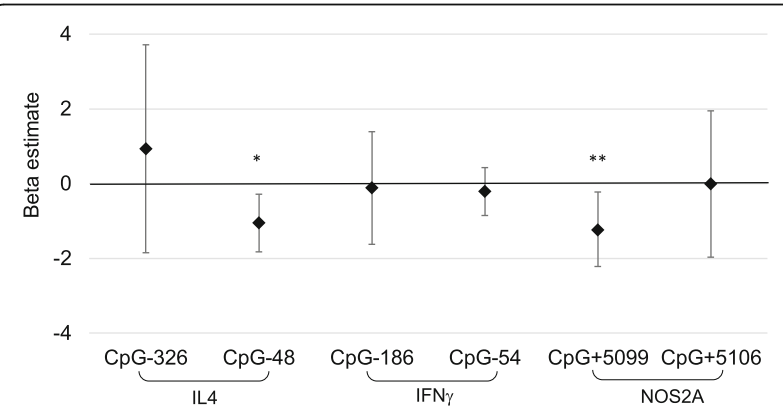

Fig. 3 Effects of DNA methylation on FeNO measured 5 days later. Beta coefficient of FeNO and $95 \% \mathrm{Cl}$ for a unit increase in log percent DNA methylation presented. Model adjusted for race/ ethnicity, sex, age, asthma diagnosis, obesity, season, and ambient $\mathrm{NO}$ on day 6 . Sixteen children were removed from the analyses of FeNO and DNA methylation due to either high ambient NO levels (>100 ppb) or equipment failure, resulting in a sample size of 127 . ${ }^{*} p<0.05$ and ${ }^{* *} p<0.01$
FeNO with IL4 $\mathrm{CpG}^{-48}$ and NOS2A $\mathrm{CpG}^{+5099}$ were not detected $(p>0.05)$.

Second, we explored the associations between IL4 and NOS2A methylation and FeNO by cockroach sensitization. The effects of IL4 $\mathrm{CpG}^{-48}$ and NOS2A $\mathrm{CpG}^{+5099}$ on FeNO measured 5 days later also seemed more apparent among cockroach-sensitized children, compared to non-sensitized children (beta estimate ( $p$ value $)=$ $-0.91(0.03)$ and $-1.31(0.01)$ for IL4 $\mathrm{CpG}^{-48}$ and NOS2A $\mathrm{CpG}^{+5099}$, respectively). To verify the possible clinical impact of these associations, we repeated the analyses on outcomes related to lung function (methods in Additional file 1). In multivariable linear regression models, demethylation of NOS2 $\mathrm{A} \mathrm{CpG}^{+5099}$, but not IL4 $\mathrm{CpG}^{-48}$, was associated with decreased forced expiratory volume in $1 \mathrm{~s} /$ forced vital capacity, $\left(\mathrm{FEV}_{1} / \mathrm{FVC}\right)$, forced expiratory flow at 25$75 \%$ of forced vital capacity $\left(\mathrm{FEF}_{25-75}\right)$, peak expiratory flow rate (PEFR), 5 days later (beta estimate $(p$ value) $=$ $0.16(<0.001), 0.56(<0.001)$, and $-1.31(<0.01)$ for $\mathrm{FEV}_{1} /$ $\mathrm{FVC}, \mathrm{FEF}_{25-75}$, and PEFR, respectively).

\section{Sensitivity analyses}

First, after removing one extreme data point (BC $\left.\geq 16 \mu \mathrm{g} / \mathrm{m}^{3}\right)$, the main findings in Table 2 and Fig. 2 remained (data not shown). Second, when the indicator of chronic exposure (i.e., the total percentage of secondary and connecting roads near a child's home address) 
was further controlled in adjusted model, the effects of $\mathrm{BC}$ on IL4 $\mathrm{CpG}^{-48}$ measured 5 days later was replicated (RR [95\% CI] 0.76 [0.61-0.95]; $p=0.017$ ). Further, in models stratified by seroatopy, the main findings in Fig. 2 remained similar after controlling for chronic exposure (RR [95\% CI] 0.72 [0.55-0.94]; $p=0.014$ and 0.73 [0.570.94]; $p=0.015$ for IL4 $\mathrm{CpG}^{-48}$ and NOS2A $\mathrm{CpG}^{+5099}$, respectively). A consistent pattern also was observed when stratified by cockroach sensitization (RR [95\% CI] 0.55 [0.37-0.83]; $p=0.004$ and 0.67 [0.45-0.98]; $p=$ 0.038 for IL4 $\mathrm{CpG}^{-48}$ and NOS2A $\mathrm{CpG}^{+5099}$, respectively). When we controlled for food intake and eliminated those on asthma/allergy medications, the main findings in Table 2 persisted (data not shown). Last, when the difference between $\mathrm{BDNA}_{1}$ and $\mathrm{BDNA}_{2}$, instead of dichotomous outcome, was used in the main analysis, a similar trend was observed for IL4 $\mathrm{CpG}^{-48}$ (but not for other loci). The higher levels of $\mathrm{BC}$ were associated with a decrease in methylation of IL4 $\mathrm{CpG}^{-48}$ over 5 days (beta estimate $(p$ value $)=-1.75(0.048))$ in multivariable linear regression model (Additional file 1 : Table S6).

\section{Discussion}

In a cohort of urban children, we found associations of 24-h averaged $\mathrm{BC}$ measured by personal monitoring on DNA hypomethylation at the IL4 promoter measured 5 days later, even after controlling for the previous methylation levels. The effects on lowering IL4 and NOS2A methylation 5 days later appeared to be greater among the seroatopic and cockroach-sensitized children. We also found that IL4 and NOS2A demethylation was associated with elevated FeNO 5 days later. Together, our results suggest that individual acute exposure to $\mathrm{BC}$ may exert delayed allergic asthma proinflammatory gene demethylation effects that in turn may link to airway inflammation. The potential susceptibility among those sensitized to cockroach observed here also may help explain previous links between cockroach sensitization and inner city asthma in children [50].

One of the strengths of this study is the assessment of $\mathrm{BC}$ using a real-time personal monitor. This approach can capture the spatial and temporal variability in traffic-related air pollution in urban settings $[51,52]$ and consider more accurately the individual mobility of older children traveling over the course of a day between school, home, and other urban locations. Presumably, measures of personal $\mathrm{BC}$ avoid misclassification of measures of time spent in specific locations that may supplement estimates from land use regression (LUR) modeling [53]. Further, the low ICC value of personal $\mathrm{BC}$ over 5 days substantiates these fluctuations in individual exposure. Another strength was the repeat buccal sample collection intended to discern some of the dynamic changes of epigenetic regulation in response to environmental exposure. We also utilized a wellphenotyped prospective birth cohort study with a rich database on each child's clinical information and chronic exposure measurements.

Our findings of an effect of short-term (24-h) BC on changes in DNA methylation and of methylation on FeNO, each 5 days later, among urban children are novel. In comparison, we did not detect the same-day effect of $\mathrm{BC}$ on lower methylation of IL4 $\mathrm{CpG}^{-48}$ and NOS2A CpG ${ }^{+5099}$. This holds true when chronic exposure to traffic-related air pollution was further controlled in the analysis, suggesting that recent acute exposure to $\mathrm{BC}$ may play an important role in the dynamics of epigenetic regulation. Several controlled human studies have reported shortterm DNA methylation changes induced by particles (i.e., concentrated ambient particles or diesel exhaust) [35, 54]. One study with older adults demonstrated that IQR increases in $\mathrm{BC}$ measured during the preceding 4 weeks were associated with significant decreases in IFNY methylation among never smokers [55]. Otherwise, to date, studies on the association between $\mathrm{BC}$ and other traffic-related air pollutants and DNA methylation are scarce, especially among children. But in one pediatric cohort, 7-day averaged levels of fine particulate matter were associated with demethylation of NOS2A [30, 56]. Our study provides the first evidence that short-term $\mathrm{BC}$ exposure may induce a delayed effect on changes of IL4 and NOS2A demethylation among children.

We found seemingly delayed effects of DNA hypomethylation of two allergic asthma genes on FeNO levels measured 5 days later. Lower methylation, consistent with the potential for greater gene expression, could underlie the reported association between measures of air pollution and increases in FeNO over this time course $[1,4,40,57]$. Analytically, here, we did not find that methylation mediated an association between $\mathrm{BC}$ and FeNO due to a lack of direct association between $\mathrm{BC}$ exposure and FeNO measured 5 days later. These findings may be a result of the study timeline, as we assessed in parallel a 5-day period of $\mathrm{BC}$ on methylation and a 5-day period of methylation on FeNO (Fig. 1). While the primary objective was to assess the association of $\mathrm{BC}$ with allergic asthma gene methylation 5 days later, our results may indicate there was a 10-day effect between $\mathrm{BC}$ exposure and $\mathrm{FeNO}$ levels. Given the high correlation between FeNO measurements over 5 days, this signal may be small. Although, our secondary analyses revealed that there was no same-day association between methylation and FeNO. Alternately, additional unmeasured environmental exposures, despite our numerous controls, could be inducing the epigenetic alterations associated with airway inflammation, or additional $\mathrm{CpG}$ loci or genes could be inducing epigenetic 
regulation of FeNO; although, insufficient power to a detect mediation effect could have been a limitation. We also acknowledge that the absence of statistical evidence of mediation by methylation on FeNO does raise some uncertainty as to underlying mechanisms. In improving the biological plausibility, we replicated the previously reported association between NOS2A methylation and lung function found in elderly men [58] and among urban children and according to a specific acute timeline.

Interestingly, we observed that the associations of DNA methylations with $\mathrm{BC}$ and $\mathrm{FeNO}$ appeared stronger among seroatopic and cockroach-sensitized children, compared to non-atopic children. Several pediatric cohorts, including ours, have investigated the effects of air pollution by asthma phenotypes $[1,59,60]$, but not in the context of environmental epigenetic regulation. One study reported stronger associations between polycyclic aromatic hydrocarbon (PAH) exposure and forkhead box P3 (FOXP3) methylation among nonasthmatic rhinitis children, compared to those among non-atopic or asthmatic children with/without rhinitis [21]. We previously reported that the association between PAH exposure and asthma was more prominent among non-atopic children, compared to that among seroatopic children [59]. However, these studies differed by age (10-14 vs 5-6 years) and air pollutants ( $\mathrm{BC}$ vs $\mathrm{PAH})$. Here, we presented that seroatopic children, especially those sensitized to cockroach allergens, may be more susceptible to the effects of $\mathrm{BC}$ on epigenetic changes and possibly airway inflammation, as a possible mechanism underlying $B C$ 's reported adjuvant effects on allergy [22].

We focused on epigenetic changes among known allergic asthma genes and previously reported regions of altered epigenetic regulation. By doing so, we were able to replicate the importance of the IL4 $\mathrm{CpG}^{-48}$, previously shown and validated as associated with urban asthma [25]. We extended this finding to show its susceptibility specifically to acute individual exposure to $\mathrm{BC}$. We also replicated the importance of NOS2A, previously shown to be associated with airway inflammation among children in Southern California/LA area [30,56]. While both studies found the link between traffic-related air pollution and demethylation of NOS2A CpG ${ }^{+5099}$ in buccal cells, new elements in our study design included the personal exposure assessment with specific focus on BC, capture of effects of an even shorter duration of exposure (24-h average instead of 7-day cumulative average), and a delayed effect of exposure. An additional distinction was the consideration of cockroach sensitization.

The reductions in allergic asthma gene methylation measured here as relative risks captured the relatively small yet significant changes in levels of methylation that were predicted to occur in daily urban living and following the behaviors of older children. We acknowledge that these small differences in single CpG sites, which essentially indicate changes among a low percent of cells within the tissues, may only partially explain the underlying immunopathogenesis. But in specific contexts, they may be reasonable surrogate measures or indicate functional differences at the cellular level [55]. Small differences (1-3\%) in methylation have been shown in previous studies to associate with several fold changes in gene expression [36, 61]. In addition, small mean differences in asthma candidate gene methylation that ranged less than $1 \%$ were associated with prenatal exposure to farm or asthma [62] and are common in environmental epigenetic studies [37]. Similar small (approximating 0.1) increases in $\mathrm{CpG}$ methylation $\beta$ values were associated with a $4.7 \%$ increase in body mass index and an 11.8 increase in fat mass index (FMI) [63]. We also related these small differences in methylation to statistically significant differences in FeNO, supporting their clinical relevance. The paradigm that the small magnitude of effect sizes found here carries additional weight because we essentially replicated previous gene links but with much finer resolution of the exposure, its timing, and relative percent methylation by $\mathrm{CpG}$ site. The findings also support previous evidence [34, 35, 64], although mixed [65], that associations can vary across gene areas.

We acknowledge several additional limitations, including the relatively small sample size necessitated by our relatively comprehensive and repeated exposure assessment. The IL4 $\mathrm{CpG}^{-326}$ findings are in the same direction as those of $\mathrm{CpG}^{-48}$ in the analysis with $\mathrm{BC}$, especially in stratified analysis by seroatopic, although not statistically significant. One explanation may be that we had insufficient statistical power to detect a difference at $\mathrm{CpG}^{-326}$ related to personal $\mathrm{BC}$ exposure. The small differences in methylation by $\mathrm{BC}$ exposure may be difficult to differentiate small differences in methylation from noise particularly at the lowest end of the spectrum as measured for ARG2 or from those measured in duplicate data [47]. We did not perform technical replicates because this procedure is not recommended by the manufacturer (Qiagen) due to the presence of several internal controls; however, blinded duplicates at extremes of methylation (e.g., very low or high) may be poorly correlated. Further, the use of categorized DNA methylation data (e.g., the highest tertile for IL4, IFN $\gamma$, and NOS2A and any methylation greater than 0 for ARG) could miss some information from that of continuous measures. Nonetheless, most of our findings remained robust during sensitivity analyses allowing us to draw some important conclusions. We targeted specific $\mathrm{CpG}$ loci in the promoter region, which was previously implicated in air pollutionrelated asthma [11, 12, 25-32] (Additional file 1: Figure S1); however, important epigenetic control mechanisms in the 
gene body beyond the promoter could be missed [66]. We do not anticipate confounding by nonhuman DNA in our buccal collections as mouths were rinsed prior to cell collections. Indeed, the main results remain the same, even after considering food intake and medication use. While unmeasured confounding is always a possibility in cohort research, the repeat measure design was intended to minimize its contribution. Even though we did detect the stronger association between $\mathrm{BC}$ and methylation among seroatopic and cockroach-sensitized children compared to non-atopic children, our analyses of effect modification indicated that they are not statistically different. Finally, sensitization to different specific allergens, such as tree, grass, ragweed, or mold, also may contribute to epigenetic changes in response to $\mathrm{BC}$ exposure.

\section{Conclusions}

These findings offer new evidence of the relatively acute and delayed temporal effects of environmental epigenetic regulation of allergic asthma genes and their differential susceptibility by allergic phenotype. Further findings suggest associations between environmental epigenetic regulation and airway inflammation. Together, these findings inform on the dynamics of environmental epigenetic regulation among a highly susceptible, mobile and difficult to capture pediatric age group.

\section{Additional file}

Additional file 1: Figure S1. Conserved promoter regions. Black lines mark loci that are conserved between human and mouse in the promoter region of IL4, IFNY, and ARG2. White areas are not conserved. Conserved regions were identified using Standard Nucleotide BLAST (blastn for more dissimilar regions; https://blast.ncbi.nlm.nih.gov/Blast.cgi.) for the 400 nucleotides upstream of the transcriptional start site (TSS) in the human sequence. The NOS2A promoter region under investigation is not conserved between mice and human. Figure S2: Schematic demonstration of collected measures. Numbers in the box represent the number of participants. $N: n=$ number of repeat subjects: number of observations. Grey dotted box indicates two measures (both time 1 and time 2, 6 months apart) available and white box only one measure (Time 1) available. $N=10$ participants dropped due to invalid personal or residential air pollution measures. $N=17$ participants were further excluded from the analysis due to missing total $\lg E(N=16)$ and invalid DNA methylation due to technical failures in the laboratory $(N=1)$, resulting in $N=136$ of the final sample size. Figure S3: Correlations between day 1 and day 6 buccal cell DNA methylations of (a) IL4

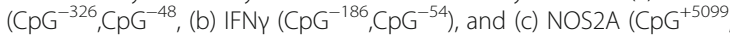
$\mathrm{CpG}^{+5106}$ ) and (d) ARG2 (average methylation of $\mathrm{CpG}^{-32}, \mathrm{CpG}^{-30}$, and $\left(\mathrm{pG}^{-26}\right)$, Spearman correlation coefficient presented. (DOCX $466 \mathrm{~kb}$ )

\section{Abbreviations}

ARG2: Arginase 2; BC: Black carbon; BDNA: Buccal DNA; CCCEH: Columbia Center for Children's Environmental Health; DEP: Diesel exhaust particle; EC: Elemental carbon; FeNO: Fractional exhaled nitric oxide; FMI: Fat mass index; FOXP3: Forkhead box P3; GEE: Generalized estimating equations; ICC: Intraclass correlation coefficient; IFNy: Interferon gamma; IgE: Immunoglobulin E; IL4: Interleukin 4; iNOS: Inducible nitric oxide synthase; IQR: Interquartile range; LUR: Land use regression; NYC: New York City; PM: Particulate Matter; RR: Relative Risk

\section{Acknowledgements}

Not applicable

\section{Funding}

This work was supported by the NIH (R01ES013163, P50ES015905, P01ES09600, 3R01ES013163-07S1, P30ES09089), EPA (R827027, RD832141, RD834509), the Educational Foundation of America, the John \& Wendy Neu Family Foundation, the New York Community Trust, and the Trustees of the Blanchette Hooker Rockefeller Fund. The funding bodies were not involved in the design of the study and collection, analysis, interpretation of the data or in the writing of the manuscript.

\section{Availability of data and materials}

The datasets generated during and/or analyzed during the current study are available from the corresponding author on reasonable request.

\section{Authors' contributions}

$\mathrm{KHJ}$ contributed to the data analyses and interpretation of results and co-wrote this manuscript with RLM. SLD contributed to the collection of samples, interpretation of results, and critical revision of the manuscript. BY contributed to the analysis of black carbon. DT contributed to the collection of the samples and analysis of the DNA methylation. JL contributed to the analysis of DNA methylation. JRJ contributed to the analysis of DNA methylation. MP contributed to the analytical approach and critical revision of the manuscript. FPP contributed to the study design and critical revision of the manuscript. SNC contributed to the study design and analysis of black carbon and provided a critical revision of the manuscript. RLM conceived of the study, supervised all study elements, helped analyze the data, and co-wrote the manuscript. All authors reviewed and approved the final manuscript.

\section{Competing interests}

None of the authors have financial relationships with a commercial entity that has an interest in the subject of this manuscript. The authors declare that they have no competing interests.

\section{Consent for publication}

No data on an individual level is provided and thus this is not applicable.

\section{Ethics approval and consent to participate}

This study has been approved by Columbia University Human Subjects protocol AAAI0459. Informed consent to participate has been obtained from the study participants or their legal guardian.

\section{Publisher's Note}

Springer Nature remains neutral with regard to jurisdictional claims in published maps and institutional affiliations.

\section{Author details}

${ }^{1}$ Division of Pulmonary, Allergy, Critical Care Medicine, Department of Medicine, Columbia University College of Physicians and Surgeons, PH8E-101, 630 W. 168 St., New York, NY 10032, USA. Division of Pediatric Pulmonary, Department of Pediatrics, College of Physicians and Surgeons, Columbia University, 630 W. 168 St., New York, NY 10032, USA. 'Lamont-Doherty Earth Observatory, Columbia University, 61 Rt, 9 W Palisades, New York 10964, USA. ${ }^{4}$ Mailman School of Public Health, Department of Environmental Health Sciences, Columbia University, 722 W. 168 St., New York, NY 10032, USA. ${ }^{5}$ Division of Pediatric Allergy, Immunology and Rheumatology, Department of Pediatrics, College of Physicians and Surgeons, Columbia University, PH8E-101, 630 W. 168 St., New York, NY 10032, USA.

Received: 20 March 2017 Accepted: 25 May 2017

Published online: 02 June 2017

\section{References}

1. Cornell AG, Chillrud SN, Mellins RB, Acosta LM, Miller RL, Quinn JW, Yan B, Divjan A, Olmedo OE, Lopez-Pintado S. Domestic airborne black carbon and exhaled nitric oxide in children in NYC. J Expo Sci Environ Epidemiol. 2012; 22(3):258-66.

2. Spira-Cohen A, Chen LC, Kendall M, Lall R, Thurston GD. Personal exposures to traffic-related air pollution and acute respiratory health among Bronx schoolchildren with asthma. Environ Health Perspect. 2011;119:559. 
3. Patel MM, Chillrud SN, Deepti K, Ross JM, Kinney PL. Traffic-related air pollutants and exhaled markers of airway inflammation and oxidative stress in New York City adolescents. Environ Res. 2013;121:71-8.

4. Rosa MJ, Perzanowski MS, Divjan A, Chillrud SN, Hoepner L, Zhang H, Ridder R, Perera FP, Miller RL. Association of recent exposure to ambient metals on fractional exhaled nitric oxide in 9-11year old inner-city children. Nitric Oxide. 2014;40:60-6.

5. Zanobetti A, Schwartz J, Dockery DW. Airborne particles are a risk factor for hospital admissions for heart and lung disease. Environ Health Perspect. 2000:108:1071.

6. Shmool JL, Kinnee E, Sheffield PE, Clougherty JE. Spatio-temporal ozone variation in a case-crossover analysis of childhood asthma hospital visits in New York City. Environ Res. 2016;147:108-14.

7. Bäumer D, Vogel B. An unexpected pattern of distinct weekly periodicities in climatological variables in Germany. Geophys Res Lett. 2007;34:L03819. doi:10.1029/2006GL028559.

8. Cerveny RS, Balling RC. Weekly cycles of air pollutants, precipitation and tropical cyclones in the coastal NW Atlantic region. Nature. 1998;394:561-3.

9. Schultz DM, Mikkonen S, Laaksonen A, Richman MB. Weekly precipitation cycles? Lack of evidence from United States surface stations. Geophys Res Lett. 2007;34: L22815. doi:10.1029/2007GL031889.

10. Miller RL, Peden DB. Environmental impacts on immune responses in atopy and asthma. J Allergy Clin Immunol. 2014;134:1001-8.

11. Niedzwiecki M, Zhu H, Corson L, Grunig G, Factor P, Chu S, Jiang H, Miller R. Prenatal exposure to allergen, DNA methylation, and allergy in grandoffspring mice. Allergy. 2012;67:904-10.

12. Sofer T, Baccarelli A, Cantone L, Coull B, Maity A, Lin X, Schwartz J. Exposure to airborne particulate matter is associated with methylation pattern in the asthma pathway. Epigenomics. 2013;5:147-54.

13. Brunst KJ, Leung Y-K, Ryan PH, Hershey GKK, Levin L, Ji H, LeMasters GK, Ho S-M. Forkhead box protein 3 (FOXP3) hypermethylation is associated with diesel exhaust exposure and risk for childhood asthma. J Allergy Clin Immunol. 2013;131:592-4.

14. Bintu L, Yong J, Anteb YE, McCue K, Kazuki Y, Uno N, Oshimura M, Elowitz MB. Dynamics of epigenetic regulation at the single-cell level. Science. 2016; 351:720-4.

15. Torrone DZ, Kuriakose JS, Moors K, Jiang H, Niedzwiecki M, Perera F, Miller RL. Reproducibility and intraindividual variation over days in buccal cell DNA methylation of two asthma genes, interferon $\gamma$ (IFN $\gamma$ ) and inducible nitric oxide synthase (iNOS). Clin Epigenetics. 2012;4:1.

16. McErlean P, Favoreto S, Costa FF, Shen J, Quraishi J, Biyasheva A, Cooper JJ, Scholtens DM, Vanin EF, de Bonaldo MF, et al. Human rhinovirus infection causes different DNA methylation changes in nasal epithelial cells from healthy and asthmatic subjects. BMC Med Genet. 2014;7:1-10.

17. Fry RC, Rager JE, Bauer R, Sebastian E, Peden DB, Jaspers I, Alexis NE. Air toxics and epigenetic effects: ozone altered microRNAs in the sputum of human subjects. Am J Physiol Lung Cell Mol Physiol. 2014;306:L1129-37.

18. He H, Ni B, Tian Y, Tian Z, Chen Y, Liu Z, Yang X, Lv Y, Zhang Y. Histone methylation mediates plasticity of human FOXP3(+) regulatory $T$ cells by modulating signature gene expressions. Immunology. 2014;141:362-76.

19. Morikawa H, Sakaguchi S. Genetic and epigenetic basis of Treg cell development and function: from a FoxP3-centered view to an epigenomedefined view of natural Treg cells. Immunol Rev. 2014;259:192-205.

20. Lee K, Richmond R, Hu P, French L, Shin J, Bourdon C, Reischl R, Waldenberger M, Zeilinger S, Gaunt T, et al. Prenatal exposure to maternal cigarette smoking and DNA methylation: epigenome-wide association in a discovery sample of adolescents and replication in an independent cohort at birth through 17 years of age. Environ Health Perspect. 2015;123:193-9.

21. Hew K, Walker A, Kohli A, Garcia M, Syed A, McDonald-Hyman C, Noth E, Mann J, Pratt B, Balmes J. Childhood exposure to ambient polycyclic aromatic hydrocarbons is linked to epigenetic modifications and impaired systemic immunity in T cells. Clin Exp Allergy. 2015;45:238-48.

22. Diaz-Sanchez D, Tsien A, Fleming J, Saxon A. Combined diesel exhaust particulate and ragweed allergen challenge markedly enhances human in vivo nasal ragweed-specific lgE and skews cytokine production to a T helper cell 2-type pattern. J Immunol. 1997;158:2406.

23. Perzanowski MS, Chew GL, Divjan A, Jung KH, Ridder R, Tang D, Diaz D, Goldstein IF, Kinney PL, Rundle AG. Early-life cockroach allergen and polycyclic aromatic hydrocarbon exposures predict cockroach sensitization among inner-city children. J Allergy Clin Immunol. 2013;131(3):886-93.
24. Jung KH, Lovinsky-Desir S, Perzanowski M, Liu X, Maher C, Gil E, Torrone D, Sjodin A, Li Z, Perera FP. Repeatedly high polycyclic aromatic hydrocarbon exposure and cockroach sensitization among inner-city children. Environ Res. 2015;140:649-56.

25. Yang IV, Pedersen BS, Liu A, O'connor GT, Teach SJ, Kattan M, Misiak RT, Gruchalla R, Steinbach SF, Szefler SJ. DNA methylation and childhood asthma in the inner city. J Allergy Clin Immunol. 2015;136:69-80.

26. Brand S, Kesper DA, Teich R, Kilic-Niebergall E, Pinkenburg O, Bothur E, Lohoff M, Garn H, Pfefferle PI, Renz H. DNA methylation of T H 1/T H 2 cytokine genes affects sensitization and progress of experimental asthma. J Allergy Clin Immunol. 2012;129:1602-10. e1606.

27. Kohli A, Garcia MA, Miller RL, Maher C, Humblet O, Hammond SK, Nadeau K. Secondhand smoke in combination with ambient air pollution exposure is associated with increasedx CpG methylation and decreased expression of IFN- $\gamma$ in T effector cells and Foxp3 in T regulatory cells in children. Clin Epigenetics. 2012;4:17.

28. Tang W-Y, Levin L, Talaska G, Cheung YY, Herbstman J, Tang D, Miller RL, Perera F, Ho S-M. Maternal exposure to polycyclic aromatic hydrocarbons and 5'-CpG methylation of interferon-[gamma] in cord white blood cells. Environ Health Perspect. 2012;120:1195.

29. Runyon RS, Cachola LM, Rajeshuni N, Hunter T, Garcia M, Ahn R, Lurmann F, Krasnow R, Jack LM, Miller RL. Asthma discordance in twins is linked to epigenetic modifications of T cells. PLoS One. 2012;7:e48796.

30. Salam MT, Byun H-M, Lurmann F, Breton CV, Wang X, Eckel SP, Gilliland FD. Genetic and epigenetic variations in inducible nitric oxide synthase promoter, particulate pollution, and exhaled nitric oxide levels in children. J Allergy Clin Immunol. 2012;129:232-9. e237.

31. Holguin F, Comhair SA, Hazen SL, Powers RW, Khatri SS, Bleecker ER, Busse WW, Calhoun WJ, Castro M, Fitzpatrick AM. An association between L-arginine/asymmetric dimethyl arginine balance, obesity, and the age of asthma onset phenotype. Am J Respir Crit Care Med. 2013;187:153-9.

32. Breton CV, Byun H-M, Wang X, Salam MT, Siegmund K, Gilliland FD. DNA methylation in the arginase-nitric oxide synthase pathway is associated with exhaled nitric oxide in children with asthma. Am J Respir Crit Care Med. 2011;184:191-7.

33. Swaminathan S, Selvam S, Thomas T, Kurpad AV, Vaz M. Longitudinal trends in physical activity patterns in selected urban south Indian school children. Indian J Med Res. 2011;134:174.

34. Lovinsky-Desir S, Ridder R, Torrone D, Maher C, Narula S, Scheuerman M, Merle D, Kattan M, DiMango E, Miller RL. DNA methylation of the allergy regulatory gene interferon gamma varies by age, sex, and tissue type in asthmatics. Clin Epigenetics. 2014;6:9.

35. Clifford RL, Jones MJ, Maclsaac JL, McEwen LM, Goodman SJ, Mostafavi S, Kobor MS, Carlsten C. Inhalation of diesel exhaust and allergen alters human bronchial epithelium DNA methylation. J Allergy Clin Immunol. 2017;139:112-21.

36. Murphy SK, Adigun A, Huang Z, Overcash F, Wang F, Jirtle RL, Schildkraut JM, Murtha AP, Iversen ES, Hoyo C. Gender-specific methylation differences in relation to prenatal exposure to cigarette smoke. Gene. 2012:494:36-43.

37. Breton CV, Marsit CJ, Faustman E, Nadeau K, Goodrich JM, Dolinoy DC, Herbstman J, Holland N, LaSalle JM, Schmidt R. Small-magnitude effect sizes in epigenetic end points are important in children's environmental health studies: the Children's Environmental Health and Disease Prevention Research Center's Epigenetics Working Group. Environ Health Perspect. 2017;125:511.

38. Valk R, Caudri D, Savenije O, Koppelman GH, Smit HA, Wijga AH, Postma DS, Kerkhof M, Brunekreef B, Jongste J. Childhood wheezing phenotypes and FeNO in atopic children at age 8. Clin Exp Allergy. 2012;42:1329-36.

39. Pijnenburg $M$, De Jongste J. Exhaled nitric oxide in childhood asthma: a review. Clin Exp Allergy. 2008;38:246-59.

40. De Prins S, Dons E, Van Poppel M, Panis LI, Van de Mieroop E, Nelen V, Cox B, Nawrot TS, Teughels C, Schoeters G. Airway oxidative stress and inflammation markers in exhaled breath from children are linked with exposure to black carbon. Environ Int. 2014;73:440-6.

41. Perera FP, IIIman SM, Kinney PL, Whyatt RM, Kelvin EA, Shepard P, Evans D, Fullilove M, Ford J, Miller RL. The challenge of preventing environmentally related disease in young children: community-based research in New York City. Environ Health Perspect. 2002;110:197. 
42. Donohue KM, Miller RL, Perzanowski MS, Just AC, Hoepner LA, Arunajadai S, Canfield S, Resnick D, Calafat AM, Perera FP. Prenatal and postnatal bisphenol A exposure and asthma development among inner-city children. J Allergy Clin Immunol. 2013;131:736-42. e736.

43. Lovinsky-Desir S, Folch C, Jung KH, Torrone D, Gil E, Perera F, Miller RL, Chillrud SN. Urban adolescents readily comply with a complicated asthma research protocol. Clin Med Insights Circ Respir Pulm Med. 2014:8:5-9.

44. Cai J, Yan B, Kinney PL, Perzanowski MS, Jung KH, Li T, Xiu G, Zhang D, Olivo C, Ross J, et al. Optimization approaches to ameliorate humidity and vibration related issues using the microAeth black carbon monitor for personal exposure measurement. Aerosol Sci Technol. 2013;47:1196-204.

45. Cai J, Yan B, Ross J, Zhang D, Kinney PL, Perzanowski MS, Jung K, Miller R, Chillrud SN. Validation of microaeth(R) as a nlack carbon monitor for fixedsite measurement and optimization for personal exposure characterization. Aerosol Air Qual Res. 2014;14:1-9.

46. Blanchard CL, Tanenbaum S, Lawson DR. Differences between weekday and weekend air pollutant levels in Atlanta; Baltimore; Chicago; Dallas-Fort Worth; Denver; Houston; New York; Phoenix; Washington, DC; and surrounding areas. J Air Waste Manage Assoc. 2008;58:1598-615.

47. Jung KH, Torrone D, Lovinsky-Desir S, Perzanowski M, Bautista J, Jezioro J, Hoepner L, Ross J, Perera F, Chillrud SN, Miller RL. Short-term exposure to PM2.5 and vanadium and changes in asthma gene DNA methylation and lung function decrements among urban children. Respir Res. 2017;18(1):63.

48. Vidal AC, Semenova V, Darrah T, Vengosh A, Huang Z, King K, Nye MD, Fry R, Skaar D, Maguire R. Maternal cadmium, iron and zinc levels, DNA methylation and birth weight. BMC Pharmacol Toxicol. 2015;16:1.

49. Zou G. A modified poisson regression approach to prospective studies with binary data. Am J Epidemiol. 2004;159:702-6.

50. Morgan WJ, Crain EF, Gruchalla RS, O'connor GT, Kattan M, Evans III R, Stout J, Malindzak G, Smartt E, Plaut M. Results of a home-based environmental intervention among urban children with asthma. N Engl J Med. 2004;351: $1068-80$.

51. Patton AP, Perkins J, Zamore W, Levy JI, Brugge D, Durant JL. Spatial and temporal differences in traffic-related air pollution in three urban neighborhoods near an interstate highway. Atmos Environ. 2014;99:309-21.

52. Jung KH, Bernabé K, Moors K, Yan B, Chillrud SN, Whyatt R, Camann D, Kinney PL, Perera FP, Miller RL. Effects of floor level and building type on residential levels of outdoor and indoor polycyclic aromatic hydrocarbons, black carbon, and particulate matter in New York City. Atmosphere. 2011;2: 96-109.

53. Mölter A, Simpson A, Berdel D, Brunekreef B, Custovic A, Cyrys J, de Jongste J, De Vocht F, Fuertes E, Gehring U. A multicentre study of air pollution exposure and childhood asthma prevalence: the ESCAPE project. Eur Respir J. 2015;45:610-624.

54. Bellavia A, Urch B, Speck M, Brook RD, Scott JA, Albetti B, Behbod B, North M, Valeri L, Bertazzi PA. DNA hypomethylation, ambient particulate matter, and increased blood pressure: findings from controlled human exposure experiments. J Am Heart Assoc. 2013;2:e000212.

55. Bind M-A, Lepeule J, Zanobetti A, Gasparrini A, Baccarelli AA, Coull BA, Tarantini L, Vokonas PS, Koutrakis P, Schwartz J. Air pollution and gene-specific methylation in the Normative Aging Study: association, effect modification, and mediation analysis. Epigenetics. 2014;9:448-58.

56. Breton CV, Salam MT, Wang X, Byun H-M, Siegmund KD, Gilliland FD. Particulate matter, DNA methylation in nitric oxide synthase, and childhood respiratory disease. Environ Health Perspect. 2012;120:1320.

57. Pollitt KJG, Maikawa CL, Wheeler AJ, Weichenthal S, Dobbin NA, Liu L, Goldberg MS. Trace metal exposure is associated with increased exhaled nitric oxide in asthmatic children. Environ Health. 2016;15:94.

58. Lepeule J, Baccarelli A, Tarantini L, Motta V, Cantone L, Litonjua AA, Sparrow D, Vokonas PS, Schwartz J. Gene promoter methylation is associated with lung function in the elderly: the Normative Aging Study. Epigenetics. 2012; 7:261-9.

59. Jung KH, Yan B, Moors K, Chillrud SN, Perzanowski MS, Whyatt RM, Hoepner L, Goldstein I, Zhang B, Camann D. Repeated exposure to polycyclic aromatic hydrocarbons and asthma: effect of seroatopy. Ann Allergy Asthma Immunol. 2012;109:249-54.
60. McCormack MC, Breysse PN, Matsui EC, Hansel NN, Peng RD, Curtin-Brosnan J, Williams D, Wills-Karp M, Diette GB. Indoor particulate matter increases asthma morbidity in children with non-atopic and atopic asthma. Ann Allergy Asthma Immunol. 2011;106:308-15.

61. Gonsky R, Deem RL, Targan SR. Distinct methylation of IFNG in the gut. $J$ Interf Cytokine Res. 2009;29:407-14

62. Michel S, Busato F, Genuneit J, Pekkanen J, Dalphin JC, Riedler J, Mazaleyrat $\mathrm{N}$, Weber J, Karvonen A, Hirvonen MR. Farm exposure and time trends in early childhood may influence DNA methylation in genes related to asthma and allergy. Allergy. 2013;68:355-64.

63. Richmond RC, Sharp GC, Ward ME, Fraser A, Lyttleton O, McArdle WL, Ring SM, Gaunt TR, Lawlor DA, Smith GD. DNA methylation and body mass index: investigating identified methylation sites at HIF3A in a causal framework. Diabetes. 2016;65(5):1231-1244.

64. Sharp AJ, Stathaki E, Migliavacca E, Brahmachary M, Montgomery SB, Dupre $Y$, Antonarakis SE. DNA methylation profiles of human active and inactive $X$ chromosomes. Genome Res. 2011;21:1592-600.

65. Sormani G, Haerter JO, Lövkvist C, Sneppen K. Stabilization of epigenetic states of CpG islands by local cooperation. Mol BioSyst. 2016;12:2142-6.

66. Ball MP, Li JB, Gao Y, Lee J-H, LeProust EM, Park I-H, Xie B, Daley GQ, Church GM. Targeted and genome-scale strategies reveal gene-body methylation signatures in human cells. Nat Biotechnol. 2009;27:361-8.

\section{Submit your next manuscript to BioMed Central and we will help you at every step:}

- We accept pre-submission inquiries

- Our selector tool helps you to find the most relevant journal

- We provide round the clock customer support

- Convenient online submission

- Thorough peer review

- Inclusion in PubMed and all major indexing services

- Maximum visibility for your research

Submit your manuscript at www.biomedcentral.com/submit
C Biomed Central 